\title{
PROFIL PENGGUNAAN AUTHENTIC ASSESSMENT DALAM PEMBELAJARAN BIOLOGI DI MADRASAH ALIYAH SE-KOTA BOGOR
}

\author{
Desti Kurniawati, Zulfiani, Nengsih Juaningsih \\ Pendidikan IPA UIN Syarif Hidayatullah Jakarta, desti.kurniawan64@gmail.com
}

\begin{abstract}
This research aims to obtain the overview about the fact systematically by biology teacher at Madrasah Aliyah Se-Bogor City. The research was carried out on the odd year semester lesson 2013/2014, begin in september and in october 2013.The methods used a survey method, which samples conducted using a purposive sampling technique. A sample of this study consisted of five madrasah tsanawiyah bogor, Madrasah Aliyah that MAN 1, MAN 2 Bogor Bogor City, MA Association of Muslims (PUI), AlGhazaly MA, and MA Al-Haitham. The instruments used the non test instrument which consists of the form of authentic assessment check list sheet, authentic assessment, and interviews. A quantitative data was analyzed by percentage of descriptive categorized according to the percentage of John Wilkinson. The results showed that the level of conformity assessment documents performance or performance appraisal documents and discussion/presentation on authentic assessment documents fifth is included in the appropriate category and the results of the now about authentic assessment has shown that the use of authentic assessment in learning biology in Madrasah Aliyah Bogor City already well categorized
\end{abstract}

Keywords: the use of authentic assessment, assessment of performance/performance assessment, discussion or presentation, learning Biology

\begin{abstract}
Abstrak
Penelitian ini bertujuan untuk memperoleh gambaran secara sistematis mengenai fakta penggunaan authentic assessment oleh guru Biologi di Madrasah Aliyah Se-Kota Bogor. Penelitian dilaksanakan pada semester ganjil tahun pelajaran 2013/2014, dimulai pada bulan September sampai dengan bulan Oktober 2013. Metode yang digunakan dalam penelitian ini adalah metode survei. Pengambilan sampel dilakukan dengan menggunakan teknik purposive sampling. Sampel penelitian ini berjumlah lima Madrasah Aliyah yaitu MAN 1 Kota Bogor, MAN 2 Kota Bogor, MA Persatuan Umat Islam (PUI), MA Al-Ghazaly, dan MA Al-Haitsam. Instrumen yang digunakan dalam penelitian ini adalah instrumen non tes yang terdiri dari dokumentasi berupa lembar daftar cek penilaian otentik, angket penilaian otentik, dan wawancara. Analisis data dilakukan terhadap data kualitatif dan kuantitatif, untuk data kuantitatif analisis data dilakukan dengan menggunakan rumus deskriptif persentase, kemudian hasil persentase dikategorikan sesuai dengan kategori persentase menurut John Wilkinson. Hasil penelitian menunjukkan bahwa tingkat kesesuaian dokumen penilaian kinerja atau unjuk kerja dan dokumen penilaian diskusi atau presentasi pada kelima dokumen penilaian otentik sudah termasuk dalam kategori sesuai dan hasil angket mengenai penilaian otentik telah menunjukkan bahwa penggunaan authentic assessment dalam pembelajaran Biologi di Madrasah Aliyah Kota Bogor sudah berkategori baik.
\end{abstract}

Kata Kunci: penggunaan authentic assessment, penilaian kinerja atau unjuk kerja, penilaian diskusi atau presentasi, pembelajaran Biologi

\section{PENDAHULUAN}

Perkembangan ilmu pengetahuan dan teknologi membawa perubahan yang sangat signifikan tehadap berbagai dimensi kehidupan manusia, baik dalam ekonomi, sosial, budaya, maupun pendidikan. Agar pendidikan tidak tertinggal perlu adanya penyesuaian-penyesuaian terutama yang berkaitan dengan faktor-faktor pembelajaran di sekolah. Salah satu faktor tersebut adalah sistem penilaian yang perlu dipelajari dan dikuasai guru, sehingga peserta didik mengetahui perkembangan belajarnya secara berkesinambungan.
Pada abad milenium kedua ini wawasan kependidikan kita telah mengalami perubahan yang sangat drastis. Apabila sebelumnya guru dipandang sebagai aktor dan instruktor yang mengatur sepenuhnya kehidupan kelas, saat ini guru diposisikan sebagai fasilitator dan motivator yang dapat mengaktifkan dan menggairahkan peserta didik berkiprah dalam kehidupan kelas.

Perubahan paradigma pendidikan tersebut juga berpengaruh kepada konsep penilaian pendidikan. Pada saat ini konsep penilaian pendidikan menunjukkan arah yang lebih luas. Penilaian tidak hanya untuk mengetahui hasil 
belajar peserta didik, tetapi juga untuk mengetahui bagaimanakah proses belajar tersebut berlangsung. Hasil belajar dipandang sebagai akibat proses belajar. Oleh karena itu, proses belajar juga perlu dinilai.

Penilaian merupakan bagian yang tak terpisahkan dalam proses pendidikan. Melalui penilaian, pelaku pendidikan mendapat gambaran sejauh mana, dalam hal apa, dan bagaimana tujuan pendidikan dapat tercapai. Oleh karena itu sistem penilaian harus disesuaikan dengan pengalaman belajar yang ditempuh dalam proses pembelajaran dan harus bermuara pada penguasaan kompetensi yang diharapkan.

Berdasarkan paradigma itulah istilah assessment muncul. Proses assessment mencakup sejumlah bukti-bukti yang menunjukkan pencapaian hasil belajar peserta didik. Assessment ini dilaksanakan secara terpadu dengan kegiatan pembelajaran sehingga disebut sebagai Penilaian Berbasis Kelas (PBK). PBK dilakukan dengan berbagai cara seperti pengumpulan kerja peserta didik (portofolio), hasil karya (product), penugasan (project), kinerja (performance), dan tes tertulis (paper and pencil). Guru menilai kompetensi dan hasil belajar peserta didik berdasarkan tingkat pencapaian prestasi peserta didik. Penilaian demikianlah yang disebut authentic assessment (penilaian otentik).

Penilaian otentik adalah proses pengumpulan informasi oleh guru tentang perkembangan dan pencapaian pembelajaran yang dilakukan anak didik melalui berbagai teknik yang mampu mengungkapkan, membuktikan atau menunjukkan secara tepat bahwa tujuan pembelajaran telah benar-benar dikuasai dan dicapai. Adapun tujuan utama kegiatan penilaian adalah untuk mengetahui apakah kompetensi dasar yang seharusnya dicapai dalam serangkaian pembelajaran sudah dikuasai peserta didik atau belum.

Untuk mengetahui sejauh mana kompetensikompetensi telah dicapai oleh peserta didik, selain menggunakan bentuk penilaian pensil dan kertas (pencil and paper test), guru juga dapat menggunakan penilaian unjuk kerja peserta didik (performance). Guru dapat menilai berdasarkan hasil kerja peserta didik, dengan cara memberikan tugas atau menganalisis semua hasil kerja mereka dalam bentuk portofolio. Penilaian juga tidak hanya menitikberatkan pada aspek kognitif, tetapi juga harus meliputi aspek tujuan lain seperti pengembangan pribadi, kreativitas, dan keterampilan interpersonal. Dengan cara demikian, maka akan diperoleh gambaran utuh tentang keunggulan atau kelemahan peserta didik.

Fakta di lapangan menunjukkan bahwa penilaian pembelajaran khususnya dalam pembelajaran sains selama ini cenderung lebih difokuskan pada penilaian ranah kognitif saja sehingga ranah afektif dan ranah psikomotoriknya kurang diperhatikan. Padahal kenyataannya pembelajaran sains di sekolah menengah menuntut keterlibatan peserta didik secara aktif dan bertujuan agar penguasaan dari kognitif, afektif, psikomotorik terbentuk pada diri peserta didik. Oleh karena itu alat ukur hasil belajarnya tidak cukup jika hanya dengan tes kogniif berupa tes obyektif atau subyektif saja. Dengan cara tersebut keterampilan siswa melakukan percobaan maupun menciptakan suatu hasil karya belum dapat diungkap. Demikian pula tentang aktivitas siswa selama mengerjakan tugas dari guru. Baik berupa tugas individu maupun kelompok.

Melihat kenyataan yang ditemukan di lapangan, nampak ada kesenjangan antara pembelajaran Biologi di SMA/MA dengan teknik penilaiannya. Proses penilaian yang biasa dilakukan guru selama ini hanya mampu menggambarkan aspek penguasaan konsep peserta didik, akibatnya sasaran belajar IPA belum dapat dicapai secara menyeluruh. Untuk itu perlu diupayakan suatu teknik penilaian yang mampu mengungkap aspek produk maupun proses.

Dalam upaya memperbaiki kondisi pembelajaran Biologi, khususnya dalam hal mengungkap penilaian yang dilakukan oleh guru, oleh karena itu penilaian otentik perlu dilaksanakan. Dengan demikian diharapkan dapat meningkatkan mutu pembelajaran Biologi dalam proses penilaian dalam pembelajaran yang dapat mengungkap ketiga ranah, yaitu kognitif, afektif dan psikomotorik pada peserta didik.

Namun, tidak semua guru mampu menyusun dokumen penilaian otentik dengan baik karena penilaian otentik baru dikenal secara teori dan konsep. Tidak semua guru mampu mengalihkannya ke dalam prosedur penilaian kelas sehari-hari. Bahkan terdapat sebagian kecil guru yang tidak mengetahui apa dan bagaimana format atau bentuk penilaian otentik, apa manfaat yang diperoleh dan komponen-komponen apa saja yang harus ada dalam sebuah instrumen penilaian otentik.

Penelitian ini akan melakukan analisis terhadap penggunaan penilaian otentik oleh guru Biologi. Penelitian ini dirasakan perlu dilakukan 
mengingat sains tidak hanya mementingkan produk saja tetapi proses dalam pembelajaran sains juga perlu dilakukan identifikasi dan penilaian.

\section{METODE PENELITIAN}

Jenis penelitian yang digunakan dalam penelitian ini adalah penelitian deskriptif dengan menggunakan metode survei. Dalam penelitian ini peneliti berusaha untuk mencari, mengumpulkan, menggambarkan, dan menafsirkan data tentang penggunaan authentic assessment dalam dokumendokumen penilaian yang disusun oleh guru Biologi. Dokumen yang terkumpul selanjutnya dianalisis kemudian diinterpretasikan.

Populasi dalam penelitian ini adalah seluruh guru Biologi yang ada di Madrasah Aliyah se-Kota Bogor. Adapun Madrasah Aliyah yang terdapat di Kota Bogor sebanyak 16 Madrasah Aliyah yang terdiri dari 2 Madrasah Aliyah Negeri dan 14 Madrasah Aliyah Swasta. Sampel yang digunakan dalam penelitian ini yaitu semua guru Biologi yang ada di Madrasah Aliyah se-Kota Bogor. Jumlah keseluruhan guru Biologi MA yang ada di Kota Bogor adalah sebanyak 24 orang. Total sampel yang digunakan dalam penelitian ini yaitu 8 orang guru Biologi. Adapun dalam pengambilan sampel pada penelitian ini menggunakan teknik purpossive sampling.

Instrumen utama yang digunakan dalam penelitian ini adalah instrumen non tes dokumentasi berupa lembar daftar cek penilaian otentik dan angket penilaian otentik. Selain itu digunakan juga pedoman wawancara untuk guru.

Peneliti melakukan teknik analisis data dengan langkah-langkah sebagai berikut. Pertama, setelah seluruh data dikumpulkan maka dilakukan reduksi data. Mereduksi data berarti merangkum, memilih hal-hal yang pokok, dan memfokuskan pada hal-hal yang penting yang berkaitan. Kedua, yaitu dengan display data (penyajian data) dengan menjumlahkan kemunculan kategori indikator dari masing-masing penilaian otentik untuk setiap dokumen penilaian yang dianalisis. Ketiga, menghitung persentase tingkat kesesuaian kemunculan indikator pada dokumen penilaian otentik dengan menggunakan rumus deskriptif persentase sebagai berikut:

Persentase $(\%)$ Kesesuaian $=$

$\frac{\Sigma \text { indikator dokumen penilaian yang muncul }}{\Sigma \text { indikator dokumen penilaian keseluruhan }} \times 100 \%$

Keempat, data hasil perhitungan tingkat kesesuaian kemudian direkapitulasi berdasarkan kategori yang diadaptasi dari John Wilkinson sebagai berikut:

$$
\begin{array}{ll}
<40 \% & : \text { Tidak Sesuai } \\
40 \%-75 \% & : \text { Sesuai } \\
>75 \% & : \text { Sangat Sesuai }
\end{array}
$$

Kelima, menghitung persentase hasil angket kemudian mengkategorikan nilai persentase berdasarkan kategori Tabel 1.

Tabel 1. Kategori Nilai Persentase

\begin{tabular}{lll}
\hline No. & $\begin{array}{l}\text { Persentase } \\
\text { Batas Interval }\end{array}$ & Kategori Penilaian \\
\hline 1. & $0-20 \%$ & Kurang Sekali \\
2. & $21-40 \%$ & Kurang \\
3. & $41-60 \%$ & Cukup \\
4. & $61-80 \%$ & Baik \\
5. & $81-100 \%$ & Sangat Baik \\
\hline
\end{tabular}

Keenam, selanjutnya, hasil dari display data serta perhitungan tingkat kesesuaian kemudian data tersebut dideskripsikan dan dianalisis untuk memperoleh jawaban dari pertanyaan penelitian. Berdasarkan hasil analisa tersebut selanjutnya data diverifikasi dan ditarik kesimpulan.

\section{HASIL DAN PEMBAHASAN}

Berdasarkan hasil survei terhadap 16 Madrasah Aliyah se-Kota Bogor, diperoleh informasi mengenai data kepemilikan dokumen authentic assessment Madrasah Aliyah se-Kota Bogor beserta implementasi penggunaan authentic assessment oleh guru Biologi.

Tabel 2 disajikan data kepemilikan dokumen authentic assessment Madrasah Aliyah se-Kota Bogor beserta data jenis-jenis authentic assessment yang digunakan oleh guru. Tabel 2 menunjukkan kurang dari separuh guru yakni $(31,25 \%)$ yang memiliki dokumen authentic assessment. Dengan demikian hanya terdapat 5 sekolah dari total 16 sekolah yang menjadi subjek penelitian yang telah memiliki dokumen authentic assessment. 
Tabel 2. Data Kepemilikan Dokumen Authentic Assessment Madrasah Aliyah se-Kota Bogor

\begin{tabular}{|c|c|c|}
\hline No. & $\begin{array}{c}\text { Nama Sekolah } \\
\text { (MA) }\end{array}$ & $\begin{array}{c}\text { Memiliki dokumen } \\
\text { authentic } \\
\text { assessment }\end{array}$ \\
\hline 1. & MA A & + \\
\hline 2. & MA B & + \\
\hline 3. & MA C & + \\
\hline 4. & MA D & - \\
\hline 5. & MA E & - \\
\hline 6. & MA F & - \\
\hline 7. & MA G & - \\
\hline 8. & MA H & - \\
\hline 9. & MA I & - \\
\hline 10. & MA J & + \\
\hline 11. & MA K & + \\
\hline 12. & MA L & - \\
\hline 13. & MA M & - \\
\hline 14. & MA N & - \\
\hline 15. & MA O & - \\
\hline \multirow[t]{2}{*}{16.} & MA P & - \\
\hline & Persentase $(\%)$ & 31.25 \\
\hline \multicolumn{3}{|c|}{ Keterangan: } \\
\hline $\begin{array}{l}\text { MA } \\
+ \\
-\end{array}$ & \multicolumn{2}{|c|}{$\begin{aligned}= & \text { Madrasah Aliyah } \\
= & \text { Memiliki dokumen authentic assessment } \\
= & \text { Tidak memiliki dokumen authentic } \\
& \text { assessment }\end{aligned}$} \\
\hline
\end{tabular}

Jenis-jenis authentic assessment yang pernah dibuat oleh guru Biologi Madrasah Aliyah dapat dilihat pada Tabel 3 .

Tabel 3. Jenis-jenis Authentic Assessment yang dibuat oleh guru Biologi

\begin{tabular}{|c|c|c|c|c|c|}
\hline \multirow[t]{2}{*}{ No. } & \multirow[t]{2}{*}{$\begin{array}{c}\text { Nama } \\
\text { Sekolah }\end{array}$} & \multicolumn{4}{|c|}{$\begin{array}{c}\text { Kelengkapan Dokumen authentic } \\
\text { assessment }\end{array}$} \\
\hline & & $\begin{array}{c}\text { Kinerja } \\
\text { /Unjuk } \\
\text { Kerja }\end{array}$ & Proyek & $\begin{array}{c}\text { Porto- } \\
\text { folio }\end{array}$ & Diskusi \\
\hline 1. & MA A & + & - & - & - \\
\hline 2. & MA B & + & - & - & + \\
\hline 3. & MA C & + & - & - & - \\
\hline 4. & MA J & + & - & - & + \\
\hline & MA K & + & - & - & + \\
\hline \multicolumn{2}{|c|}{$\begin{array}{l}\text { Presentase } \\
(\%)\end{array}$} & 100 & 0 & 0 & 60 \\
\hline \multicolumn{6}{|l|}{$\begin{array}{l}+ \\
-\end{array}$} \\
\hline \multicolumn{6}{|c|}{$\begin{array}{l}\text { Data Tabel 3, ternyata hanya dua jenis } \\
\text { authentic assessment yang dibuat oleh guru yaitu } \\
\text { penilaian unjuk kerja dan penilaian diskusi. Hal ini } \\
\text { disebabkan karena authentic assessment baru } \\
\text { dikenal secara teori dan konsep saja, sehingga tidak } \\
\text { semua guru mampu mengaplikasikannya ke dalam } \\
\text { prosedur penilaian kelas sehari-hari. }\end{array}$} \\
\hline
\end{tabular}

Hasil wawancara dengan guru juga, diperoleh informasi bahwa guru merasa kesulitan dalam membuat skoring dan rubrik penilaiannya, terutama untuk penilaian proyek dan penilaian portofolio. Guru juga belum mengetahui cara membuat rubrik dan skoring yang benar dalam melaksanakan authentic assessment sehingga format penilaiannya pun dibuat berdasarkan pengalaman dari guru tersebut. Sehingga dokumen yang diperoleh peneliti pun hanya dokumen penilaian unjuk kerja dan dokumen penilaian diskusi.

Hal ini sejalan dengan pendapat dari Airasian \& Stiggins Brualdi Timmins (2008).

The benefit of performance class assessments are well documented. However, some teachers are hesitant to implement them in their classrooms. Commonly, this is because these teachers feel they don't know enough about how to fairly assess a student's performance (Airasian, 1991). Another reason for reluctance in using performance class assessments may be previous experiences with them when the execution was unsuccessful or the results were inconclusive.

Jika diartikan, manfaat dari penilaian berbasis kelas jika didokumentasikan akan baik. Namun, beberapa guru ragu-ragu untuk menerapkannya di dalam kelas mereka. Umumnya, hal ini karena guru-guru ini merasa tidak cukup tahu tentang bagaimana menilai kinerja siswa (Airasian, 1991). Alasan lain untuk keengganan dalam menggunakan penilaian berbasis kelas mungkin pengalaman sebelumnya dengan mereka ketika eksekusi tidak berhasil atau hasilnya tidak konklusif (Stiggins, 1994).

Di dalam sebuah teori menyatakan bahwa penentuan kriteria dan format penilaian pada portofolio disusun sebagai standar patokan untuk guru dalam menentukan keberhasilan proses dan hasil pembelajaran pada setiap aspek yang akan dinilai. Adapun aspek-aspek yang dinilai tersebut sangat tergantung pada jenis kompetensi yang diharapkan. Selanjutnya kriteria aspek tersebut disusun dalam sebuah format penilaian yang jelas. Sama halnya dengan penilaian proyek, penilaian terhadap suatu tugas yang mengandung investigasi harus selesai dalam waktu tertentu. Investigasi dalam penugasan memuat beberapa tahapan, yaitu perencanaan, pengumpulan data, pengolahan data, dan penyajian data. Sedangkan untuk aspek-aspek kriteria yang akan digunakan untuk menilai peserta 
didik dalam penilaian proyek disesuaikan dengan standar kompetensi yang akan dicapai.

Dengan demikian, pembuatan format penilaian portofolio dan penilaian proyek memang belum ada aturan yang khusus, tetapi guru diberikan kebebasan untuk menyusunnya sendiri berdasarkan standar kompetensi dan acuan yang sudah ditetapkan oleh guru tersebut dan berdasarkan kriteria-kriteria apa saja yang harus dicapai oleh peserta didik. Berdasarkan data analisis yang telah diperoleh maka dapat diambil kesimpulan pada grafik yang tersaji di bawah ini.

Kemunculan indikator penilaian kinerja atau /unjuk kerja untuk setiap dokumen atau instrumen penilaian kinerja atau unjuk kerja kelas X, XI, dan XII dari setiap sekolah, dapat dilihat pada Gambar 1.

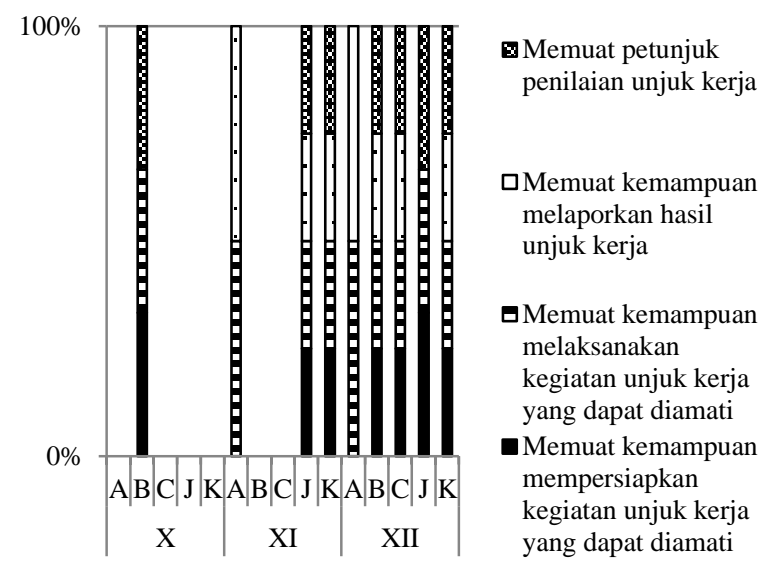

Gambar 1. Instrumen Penilaian Kinerja atau Unjuk Kerja Kelas X, XI, dan XII dari setiap sekolah

Gambar 1 menunjukkan bahwa indikator yang paling banyak muncul dari setiap dokumen penilaian kinerja atau unjuk kerja $\mathrm{A}, \mathrm{B}, \mathrm{C}, \mathrm{J}$, dan $\mathrm{K}$ yaitu indikator ke 2 yakni memuat kemampuan melaksanakan kegiatan unjuk kerja yang dapat diamati, dengan jumlah total 9 yang muncul dari seluruh dokumen kelas $\mathrm{X}$, XI, dan XII pada masing-masing dokumen penilaian $\mathrm{A}, \mathrm{B}, \mathrm{C}, \mathrm{J}$, dan K. Sedangkan pada indikator ke 1,3, dan 4, jumlah kemunculan indikator sebanyak 7 dari total seluruh dokumen kelas X, XI, dan XII pada masing-masing dokumen penilaian A, B, C, J, dan $\mathrm{K}$.

Persentase kesesuaian dokumen penilaian kinerja atau unjuk kerja kelas X, XI, dan XII dari setiap sekolah, dilihat pada Gambar 2.



\section{Gambar 2. Persentase Kesesuaian Dokumen Penilaian Kinerja atau Unjuk Kerja Kelas X, XI, dan XII dari setiap sekolah}

Pada Gambar 2 menunjukkan bahwa pada dokumen penilaian MA A persentase kesesuaian dokumen penilaian kinerja/unjuk kerja kelas XI diperoleh sebesar 50\% dengan kategori sesuai, begitu juga dengan dokumen penilaian kinerja/unjuk kerja kelas XII diperoleh persentase kesesuaian sebesar 50\% dengan kategori sesuai. Pada dokumen penilaian kinerja atau unjuk kerja MA B kelas X diperoleh persentase kesesuaian sebesar $75 \%$ dengan kategori sesuai sedangkan pada dokumen penilaian kelas XII diperoleh persentase kesesuaian sebesar $100 \%$ dengan kategori sangat sesuai. Pada dokumen penilaian kinerja/unjuk kerja MA C kelas XII diperoleh persentase kesesuaian sebesar 100\% dengan kategori sangat sesuai. Pada dokumen penilaian MA J persentase kesesuaian dokumen penilaian kinerja/unjuk kerja kelas XI diperoleh sebesar $100 \%$ dengan kategori sangat sesuai sedangkan pada dokumen penilaian kinerja atau unjuk kerja kelas XII diperoleh persentase kesesuaian sebesar $75 \%$ dengan kategori sesuai. Pada dokumen penilaian MA K baik kelas XI maupun kelas XII diperoleh persentase kesesuaian sebesar 100\% dengan kategori sangat sesuai.

Kemunculan indikator penilaian diskusi atau presentasi untuk setiap dokumen atau instrumen penilaian diskusi atau presentasi yang dianalisis, dapat dilihat pada Gambar 3. 


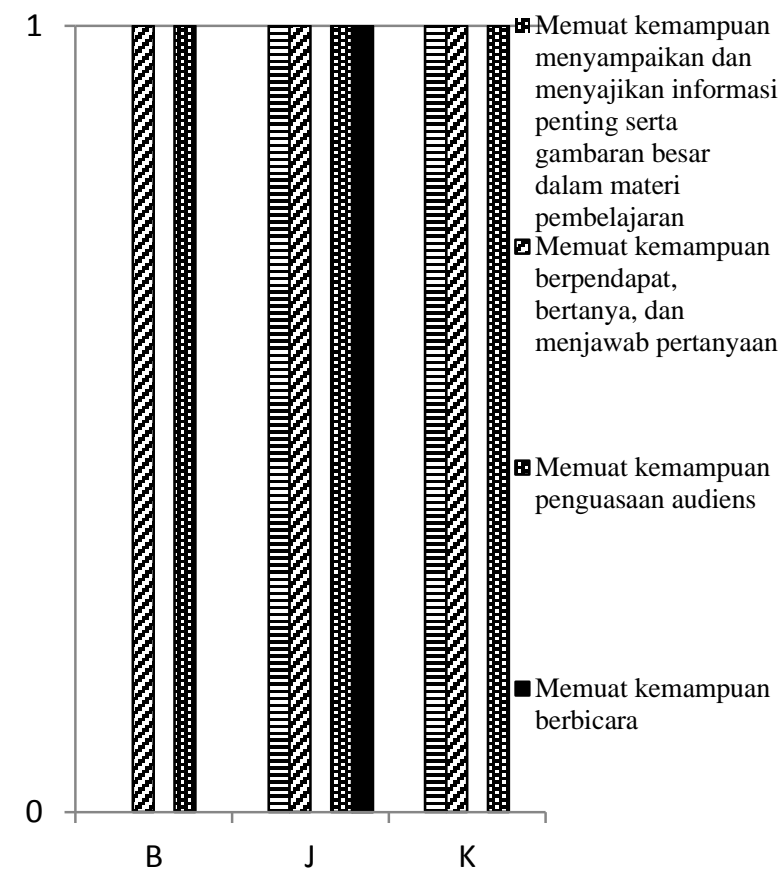

Gambar 3. Kemunculan Indikator Penilaian Diskusi atau Presentasi untuk Setiap Dokumen atau

Instrumen Penilaian Diskusi atau Presentasi yang Dianalisis

Gambar 3 menunjukkan bahwa indikator yang paling banyak muncul dari setiap dokumen penilaian diskusi atau persentasi $\mathrm{B}, \mathrm{J}$, dan $\mathrm{K}$ yaitu indikator ke 2 dan 3 . Indikator tersebut muncul di ketiga dokumen penilaian B, J, dan K. Sedangkan pada indikator ke 1 muncul di dokumen penilaian $\mathbf{J}$ dan K. Pada indikator ke 4 hanya muncul pada dokumen penilaian J. Dengan demikian dokumen penilaian $\mathbf{J}$ sudah lengkap yakni seluruh indikator pada penilaian diskusi atau presentasi muncul di dokumen penilaian J. Persentase kesesuaian dokumen penilaian diskusi atau presentasi dapat dilihat pada Gambar 4.

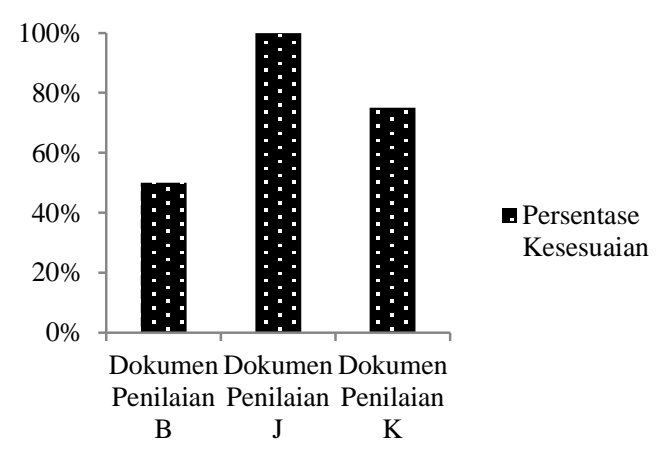

Gambar 4. Persentase Kesesuaian Dokumen Penilaian Diskusi/Presentasi
Gambar 4 menunjukkan bahwa pada dokumen penilaian diskusi atau presentasi MA J persentase kesesuaian dokumen penilaian diperoleh sebesar $100 \%$ dengan kategori sangat sesuai. Sedangkan pada dokumen penilaian MA K diperoleh persentase kesesuaian sebesar 75\% dengan kategori sesuai. Namun pada dokumen penilaian MA B diperoleh persentase kesesuaian sebesar 50\% dengan kategori sesuai.

Adapun hasil angket mengenai penggunaan authentic assessment dalam pembelajaran Biologi berdasarkan persentase dari setiap indikator pada Tabel 4, diperoleh persentase pada indikator yang pertama yaitu $71,25 \%$ dengan kategori baik, indikator kedua yaitu $64 \%$ dengan kategori baik, indikator ketiga yaitu 71,25\% dengan kategori baik, dan indikator keempat yaitu 82,5\% dengan kategori sangat baik. Dengan demikian diperoleh rata-rata dari keempat indikator tersebut yaitu $72,25 \%$. Hal ini menunjukkan bahwa penggunaan authentic assessment dalam pembelajaran Biologi di Madrasah Aliyah Kota Bogor yaitu berkategori "baik".

Tabel 4. Persentase Angket Authentic Assessment dalam Pembelajaran Biologi

\begin{tabular}{|c|c|c|}
\hline Indikator & Persentase & Kategori \\
\hline $\begin{array}{l}\text { Pengetahuan } \\
\text { authentic } \\
\text { assessment }\end{array}$ & $\begin{array}{l}\frac{57}{80} \times 100 \% \\
=71,25 \%\end{array}$ & Baik \\
\hline $\begin{array}{l}\text { Perencanaan } \\
\text { authentic } \\
\text { assessment }\end{array}$ & $\begin{array}{l}\frac{128}{200} \times 100 \% \\
=64 \%\end{array}$ & Baik \\
\hline $\begin{array}{l}\text { Implementasi } \\
\text { authentic } \\
\text { assessment }\end{array}$ & $\begin{array}{l}\frac{57}{80} \times 100 \% \\
=71,25 \%\end{array}$ & Baik \\
\hline $\begin{array}{l}\text { Pelaporan hasil } \\
\text { authentic } \\
\text { assessment }\end{array}$ & $\begin{array}{l}\frac{33}{40} \times 100 \% \\
=82,5 \%\end{array}$ & $\begin{array}{l}\text { Sangat } \\
\text { Baik }\end{array}$ \\
\hline Rata-rata & $72,25 \%$ & Baik \\
\hline
\end{tabular}

Sampai saat ini peneliti belum menemukan adanya aturan baku mengenai format penilaian otentik dalam hal ini penilaian kinerja/unjuk kerja dan penilaian diskusi/presentasi, dan proporsi yang ideal dari masing-masing indikator. Namun demikian, dokumen penilaian kinerja atau unjuk kerja dan dokumen penilaian diskusi atau presentasi yang sudah mengidentifikasi indikator-indikator yang telah peneliti kembangkan hendaknya memuat semua indikator dalam dokumen penilaian kinerja atau unjuk kerja dan dokumen penilaian diskusi atau presentasi yang sudah dibuat guru, karena indikator tersebut digunakan sebagai indikator pencapaian keterampilan peserta didik dalam mencapai kompetensi pembelajaran. 
Perhatian mengenai penggunaan penilaian otentik dalam hal ini penilaian kinerja/unjuk kerja dan penilaian diskusi atau presentasi sangat perlu untuk dikembangkan, agar tidak ada lagi yang beranggapan bahwa pelajaran sains khususnya Biologi adalah mata pelajaran yang rumit yang menekankan hanya pada hafalan konsep, teori, hukum, dan fakta.

Penilaian otentik perlu dilakukan, sebab peningkatan kualitas penilaian guru pada siswa harus melalui meningkatkan keterlibatan siswa, proses, dan tindak lanjut hasil penilaiannya. Pada peningkatan kualitas perencanaan, yang perlu dilakukan guru adalah dengan meningkatkan transparansi kriteria penilaian. Hal ini dikarenakan semakin jelas dan transparan suatu kriteria penilaian yang digunakan guru maka peserta didik akan semakin terpacu untuk dapat memenuhi kriteria yang telah ditetapkan guru. Demikian juga untuk peningkatan kualitas proses pembelajaran sebaiknya guru memperkaya variasi model dan metode pembelajaran yang disesuaikan dengan materi dan kondisi peserta didik.

Penilaian yang komprehensif, berkelanjutan, dan yang mampu mengungkapkan keterampilan peserta didik merupakan salah satu tujuan untuk mencapai kompetensi peserta didik yang lebih baik di masa sekarang dan yang akan datang.

\section{PENUTUP}

Berdasarkan hasil penelitian yang telah dilakukan maka dapat disimpulkan, yaitu ditemukan bahwa $31.25 \%$ atau sebanyak 5 sekolah dengan 8 orang guru Biologi yang telah memiliki dokumen penilain otentik. Secara umum tingkat kesesuaian dokumen penilaian kinerja/unjuk kerja dan dokumen penilaian diskusi atau presentasi pada kelima dokumen penilaian otentik di kelas X, XI, dan XII termasuk dalam kategori "sesuai" dalam mengukur indikator-indikator penilaian kinerja atau unjuk kerja dan indikator penilaian diskusi atau presentasi. Berdasarkan hasil angket mengenai authentic assessment telah menunjukkan bahwa penggunaan authentic assessment dalam pembelajaran Biologi di Madrasah Aliyah Kota Bogor sudah berkategori "baik".

\section{DAFTAR PUSTAKA}

Airasian PW. 1991. Classroom Assessment. New York: McGraw Hill.

Ariev PR, Loyola C. 2005. A Theoretical Model For The Authentic Assessment of Teaching.
Journal of Practical Assessment, Research and Evaluation 10.

Arikunto S. 2010. Prosedur Penelitian Suatu Pendekatan Praktik. Jakarta: PT Rineka Cipta.

. 2007. Manajemen Penelitian. Jakarta: PT Rineka Cipta.

Dimartino J. Authentic Assessment. Journal of Principal's Research Review 2, 2007.

Frey, Bruce B, et.al. 2012. Defining Authentic Classroom Assessment. Journal of Practical Assessment, Research and Evaluation 17.

Hakim L. 2009. Perencanaan Pembelajaran. Bandung: CV Wacana Prima.

Hamid MS. 2011. Standar Mutu Penilaian Dalam Kelas. Yogyakarta: Diva Press.

Haryati M. 2013. Model dan Teknik Penilaian Pada Tingkat Satuan Pendidikan. Jakarta: Referensi.

Haryono A. 2009. Authentic Assessment dan Pembelajaran Inovatif dalam Pengembangan Kemampuan Siswa. Jurnal Pendidikan Ekonomi 2.

Hasbi AP. 2012. "Analisis Penilaian Kinerja Pada Konsep Gerak Di Madrasah Aliyah Kabupaten Karawang Berdasarkan Keterampilan Proses Sains", Skripsi pada UIN Syarif Hidayatullah Jakarta, Tidak dipublikasikan.

Lombardi, Marilyn M. 2008. "Making the Grade: The Role of Assessment in Authentic Learning." Paper in Educause Learning Initiative. London: 2 Januari 2008.

Mahmud. 2011. Metode Penelitian Pendidikan. Bandung: CV Pustaka Setia.

Majid A. 2007. Perencanaan Pembelajaran; Mengembangkan Standar Kompetensi Guru. Bandung: PT Remaja Rosda Karya.

2014. Pembelajaran Tematik Terpadu. Bandung: PT Remaja Rosda Karya.

Moskal, Barbara M. 2009. Recommendations for Developing Classroom Performance Assessments and Scoring Rubrics. Journal of Practical Assessment, Research and Evaluation 8.

Muslich M. 2011. Authentic Assessment: Penilaian Berbasis Kelas dan Kompetensi. Bandung: PT Refika Aditama. 
2009. KTSP Pembelajaran Berbasis Kompetensi Dan Kontekstual. Jakarta: Bumi Aksara, Cet. VI.

Palm T. 2008. Performance Assessment and Authentic Assessment: A Conceptual Analysis of the Literature. Journal of Practical Assessment, Research and Evaluation 13.

Purwanto MN. 2013. Prinsip-Prinsip Dan Teknik Evaluasi Pengajaran. Bandung: PT Remaja Rosda Karya.

Rasyid H, Mansur. 2009. Penilaian Hasil Belajar. Bandung: CV Wacana Prima.

Rudner ML. 2010. "Oral Presentations for Tutorials $\&$ Seminars." Paper in The Learning Centre. The University of New South Wales. Saebani, Beni Ahmad. 2008. Metode Penelitian. Bandung: CV Pustaka Setia.

Sanjaya W. 2011. Pembelajaran Dalam Implementasi Kurikulum Berbasis Kompetensi. Jakarta: Kencana Prenada Media Group.

Sofyan A, dkk. 2006. Evaluasi Pembelajaran IPA Berbasis Kompetensi. Jakarta: UIN Jakarta Press.

Sudjana N. 2009. Penilaian Hasil Proses Belajar Mengajar. Bandung: PT. Remaja Rosdakarya.
Sugiyono. 2009. Metode Penelitian Pendidikan Pendekatan Kuantitatif, Kualitatif dan $R \& D$. Bandung: Alfabeta Stiggins R. 1994. Student

Center Classroom Assesment. New York: Merrill.

Storz C. 2009. "Oral Presentation Skills A Practical Guide." Paper in Institute National De Telecommunications. Evry France.

Sukmadinata NS. 2011. Metode Penelitian Pendidikan. Bandung: PT Remaja Rosdakarya.

Surapranata S. 2004. Panduan Penulisan Tes Tertulis Implementasi Kurikulum 2004. Bandung: PT Remaja Rosda Karya.

Timmins AB. 2008. Implementing Performance Assessment In The Classroom. Journal of Practical Assessment, Research and Evaluation. 6.

Uno HB. 2010. Perencanaan Pembelajaran. Jakarta: PT Bumi Aksara.

Yamin M. 2009. Strategi Pembelajaran Berbasis Kompetensi. Jakarta: Gaung Persada Press.

Zim, Sher A, Khan Mohammad. 2012. Authentic Assessment: An Instructional Tool to Enhance Students Learning. Journal of Academic Research International 2.

Zulfiani, dkk. 2009. Strategi Pembelajaran IPA. Jakarta: Lembaga Penelitian UIN Jakarta. 